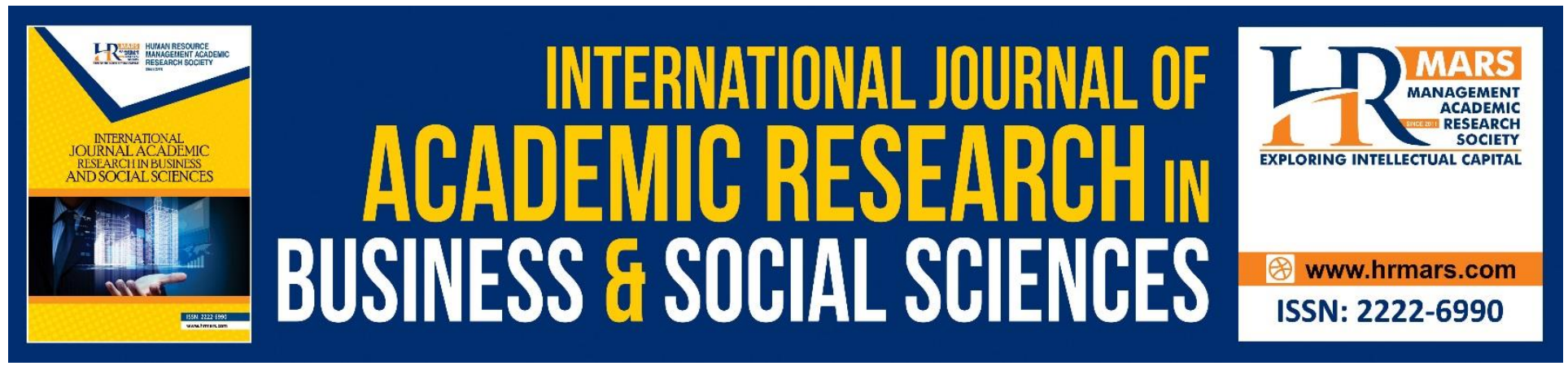

\title{
School Leaders' Competencies that make a difference in the Era of Education 4.0: A Conceptual Framework
}

\author{
Tai Mei Kin, Omar Abdull Kareem
}

To Link this Article: http://dx.doi.org/10.6007/IJARBSS/v9-i4/5836

DOI: $10.6007 /$ IJARBSS/v9-i4/5836

Received: 12 March 2019, Revised: 20 April 2019, Accepted: 1 May 2019

Published Online: 25 May 2019

In-Text Citation: (Kin \& Kareem, 2019)

To Cite this Article: Kin, T. M., \& Kareem, O. A. (2019). School leaders' competencies that make a difference in the era of Education 4.0: A conceptual framewor. International Journal of Academic Research in Business and Social Sciences, 9(5), 214-225.

\section{Copyright: (C) 2019 The Author(s)}

Published by Human Resource Management Academic Research Society (www.hrmars.com)

This article is published under the Creative Commons Attribution (CC BY 4.0) license. Anyone may reproduce, distribute, translate and create derivative works of this article (for both commercial and non-commercial purposes), subject to full attribution to the original publication and authors. The full terms of this license may be seen

at: $\underline{\text { http://creativecommons.org/licences/by/4.0/legalcode }}$

Vol. 9, No. 4, 2019, Pg. 214 - 225

http://hrmars.com/index.php/pages/detail/IJARBSS

JOURNAL HOMEPAGE

Full Terms \& Conditions of access and use can be found at http://hrmars.com/index.php/pages/detail/publication-ethics 


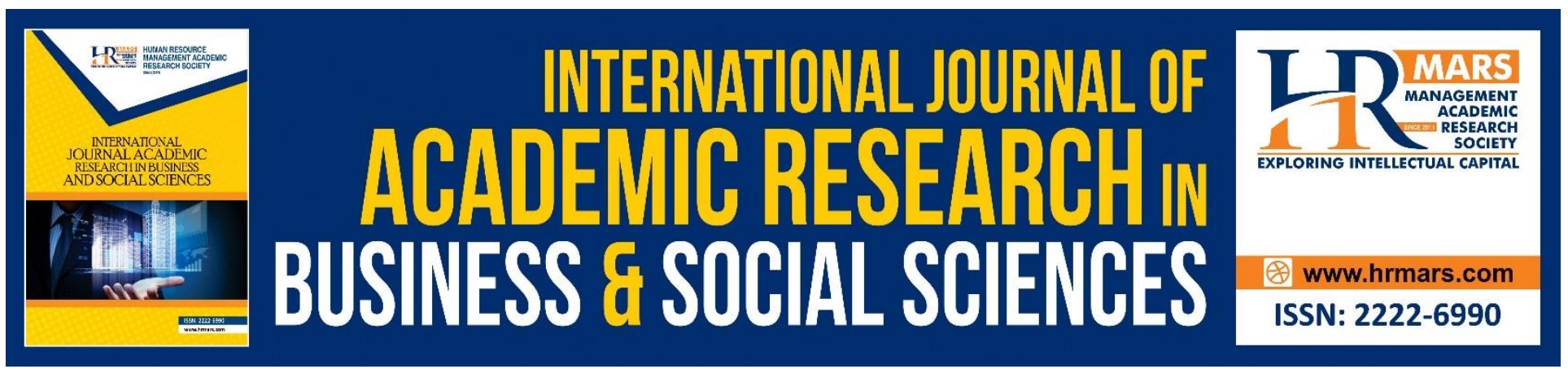

\title{
School Leaders' Competencies that make a difference in the Era of Education 4.0: A Conceptual Framework
}

\author{
Tai Mei Kin ${ }^{1}$, Omar Abdull Kareem² \\ $1 \& 2$ Department of Educational Management, Faculty of Management and Economics \\ Sultan Idris Education University, 35900 Tanjong Malim \\ Perak Darul Ridzuan, Malaysia \\ Email: taimeikin@fpe.upsi.edu.my
}

\section{Abstract}

The Fourth Industrial Revolution (FIR) has already moved past our doorstep and has influenced unprecedented changes in every industry. The educational ecosystem is no exception and Education 4.0 has been developed to respond to these new demands. As the quality of school leadership is one of the important determinants of student outcomes, and effective school management is heavily dependent on school leaders' professional competencies, there is an urgent need to re-skill or upskill school leaders' competency to prepare the country to compete in FIR. While the need of effective school leadership for the era of Education 4.0 is widely acknowledged, there is much less certainty about which leadership behaviors are most likely to produce favorable outcomes. The conceptual framework derived in this paper provides a basis for identifying the critical educational leadership competencies that include a) Leading for Learning; b) Integrity and Accountability; c) Communication; d) Collaboration; e) Critical Thinking; f) Creative and Innovative; g) Decision Making; h) Problem Solving; i) Managing Change; j) Entrepreneurial; k) Digital Literacy; and I) Emotional Intelligence. The paper may provide useful feedback in designing future training programmes for school leaders in enhancing their competence in meeting the needs and challenges of Education 4.0.

Keywords: School Leadership; Competency; Education 4.0; the Fourth Industrial Revolution; Educational Transformation; School Leadership Professional Development

\section{Introduction}

We are in the midst of the Fourth Industrial Revolution or Industry 4.0. Innovative technology has transformed the social, economic, ecological and cultural aspects of life rapidly. The educational ecosystem is no exception and Education 4.0 has been developed to respond to these new demands so that the education arena can stay current and effective in a landscape of constant change. Schools are at the core of education and thus are facing unprecedented changes and challenges to prepare 
students in meeting changing education needs in the era of the Education 4.0 that has given a new impetus to educational transformation.

As the main change agents in the school reforms, school leaders have the daunting task of building an effective learning ecosystem to prepare students for a future in the Industrial Revolution 4.0 era. They need to balance external demands with the paramount need to reorganize and reengineer schools especially pertaining learning and teaching processes. As such, the capacity to act, rather than the capacity to think, becomes the critical measure for effective school leadership. The success or failure of these actions would determine not only the future of the students, but also the power of the nation. Hence, the need for effective school leadership with effective competence to meet the complex and multifaceted demands of the Education 4.0 era is indisputable. This legitimizes the need for something 'new' in school leadership capacity especially their competence to best lead change in schools.

This situation has called for a closer examination of school leaders' competencies as their competence links significantly with student achievements (Tai \& Omar, 2018c). Towards this end, the question posed is whether Malaysian school leaders are sufficiently competent to lead school change effectively and transform the school system successfully. Although the need of effective school leadership for the era of Education 4.0 is widely acknowledged, there is much less certainty about which leadership behaviors are most likely to produce favorable outcomes. Indeed, to equip school leaders with adequate competencies to lead school change effectively in this Education 4.0 era, we need a reliable and valid model to identify those critical leadership competencies which can help school leaders to gauge school improvement and effectiveness.

Although there are various models on school leadership competency but these models mostly are developed in Western educational settings. As the historical, cultural contexts and education system of Malaysia is different from those in Western countries, the lack of scientifically sound and local developed model on school leadership competency for the era of Education 4.0 necessitates a study to identify those critical competencies. Considering school leadership as a significant predictor of effective school reform (Hallinger, 2011; Huber \& Muijs, 2010; Welch \& Hodge, 2018), therefore, to develop an indigenous school leadership competency model in the era of Education 4.0 from Malaysian perspective is imperative and appears to be a meaningful task.

The Malaysia Education Blueprint 2013-2025 was launched to transform the Malaysian education system to be on par with advanced countries. One important aspiration is to have a high quality school principal in every school because they are the transformational leaders who are expected to lead change effectively (Ministry of Education Malaysia, 2016). Unless school leaders are equipped with subsequent competencies and initiate the process competently, school reform will fall short of the ambitious aspirations set out in the Blueprint. Hence, school leadership development is an urgent priority in order to bring about effective educational leadership that reform and transform. If school leadership is examined from a behavioral construct based on competencies, and focus on the most critical competencies that can be learned, there is little doubt that processes of school leadership development can be fine-tuned for greater efficiency; specifically in enhancing leadership capacity to respond to the needs of the Education 4.0 and ultimately to transform the school system effectively. 
INTERNATIONAL JOURNAL OF ACADEMIC RESEARCH IN BUSINESS AND SOCIAL SCIENCES

Vol. 9, No. 4, April, 2019, E-ISSN: 2222-6990 @ 2019 HRMARS

\section{Literature Review}

\section{The Fourth Industrial Revolution and Education $\mathbf{4 . 0}$}

Industrial revolutions have evolved in several stages for 200 years since its first emergence. Every industrial revolution has had significant impact on global society, and the Fourth Industrial Revolution is no different. The main characteristic of the Fourth Industrial Revolution is the interconnectedness of the whole value chain in the global society that has weaved together supposedly autonomous systems created by intelligent networks of machines and data; the four crucial components for this new era are the internet of things, the internet of data, the internet of services, and the internet of people (Herold, 2016). Technology has become integrated into virtually every facet of life, influencing our lifestyles and values significantly.

To respond to the demands of Industry 4.0, Education 4.0 was developed and this has given a new impetus to educational transformation in terms of pedagogy, content, curricula and educational management. For instance, instead of traditional teaching aids, technology-based tools and resources are being used to drive education in non-traditional ways (Tang, Wong \& Cheng, 2015); teachers become facilitators of learning, rather than repositories of cultural wisdom to be delivered to their students (Dubovicki \& Jukic, 2017). Instead of maintaining an exclusive focus on cognitive development, schools are places to construct knowledge and ideas (O' Flaherty \& Beal, 2018). More importantly, the nature of learning is a uniquely personal and social activity between people that caters to every learner's changing needs, talent, passion and interest (Brown-Martin, 2018).

Therefore, it is believed that Education 4.0 will empower students towards innovations, resulting in raising achievement levels and greater student learning outcomes. Consequently, it creates trained, qualified professionals who are equipped with interdisciplinary thinking, social skills and other technical skills for a highly globalised and technological-driven world of work (Brown-Martin, 2018). Education is at the heart of preparing present and future generations to thrive in the competitive world (Mohamed, Valcke \& De Wever, 2017). Transforming the education system from one that is based on facts and procedures, to one that actively applies knowledge to collaborative problem solving in the real world will be the main characteristic of Education 4.0 that will help overcome the challenges of Industry 4.0.

\section{School leadership and competency}

Leadership plays a critical role in any organizational development. The changing global conditions in the era of Industrial Revolution 4.0 such as the intensifying efficiency requirements, the pressing need for continuing learning and the advanced digital technologies call for new approaches to organizational leadership (Lappalainen, 2015). Over the last decade, research in leadership development has moved towards identifying the leadership competencies that help to accomplish organizational goals (Bitterova, Haskova \& Pisonova, 2014; Shet, Patil \& Chandawarkar, 2017). Generally, competencies are viewed as clusters of knowledge, skills, abilities and behaviours that demonstrate excellent performance (Duffy, 2009). These elements differentiate between leaders from non-leaders (Bharwani \& Talib, 2017; Bueno \& Tubbs, 2005).

In the field of education, leadership role is changing along with the shifting expectations for educational excellence. School leaders need to respond to the needs of the Education 4.0 with sufficient competencies so as they can be the effective leaders who can bring the schools to the 
transformational edge. As effective leadership is of central concern in school system (Ministry of Education, 2016), it is essential for school leaders to be agile and adapt their leadership practice to meet the needs of the students, stakeholders and the school systems in the era of Education 4.0 globally and locally. With the increasing demands for educational excellence, school leaders can only become effective leaders unless they are able to gain new knowledge, skills and ability through effective professional development programmes or interventions systematically and continually.

In an attempt to identify competencies that predict effective school leadership in the era of Education 4.0 in Malaysia, few aspects need to be taken into consideration: a) the special features of the schools especially about its moral purpose and the core workforce is professional (Hallinger \& Walker, 2017; Wendy Pan, Nyeu \& Cheng, 2017); b) the major trends that have been identified occurring in the area of school leadership (Abrahamsen \& Aas, 2016; Leithwood, Harris \& Hopkins, 2008; Townsend, 2011); c) qualities of effective school leaders identified by extensive educational research (Bitterov et al., 2014; Day \& Sammons, 2013; Drydale \& Gurr, 2011; Freeman \& Auster, 2011; Gray \& Streshly, 2010; Hallinger \& Huber, 2012; Welch \& Hodge, 2018); d) the contextual changes and future challenges in Malaysian education system (Ministry of Education Malaysia; 2016; Samuel, Tee \& Pe Symaco, 2017); and e) future trends in leadership development across industries (Ng, 2015; Petrie, 2014; Shet et al., 2017).

\section{The Conceptual Framework of the study}

The study is confined to one variable i.e. school leadership competency for the era of education 4.0 with 12 respective indicators. As shown in Figure 1, a total of twelve competencies have been identified for the study. The inner circle illustrates the core focus of school leaders' competency --Leading for Learning. In the pursuit of teaching and learning excellence in the era of Education 4.0, instead of 'knowledge feeding', school leaders need to be competent of how to lead and influence teachers playing their role in constructing knowledge on teaching and learning (Wendy Pan et al., 2017). Indeed all change involves learning. Propelled by a deep personal desire to learn and a commitment to help teachers learn, the school leaders are learners first, leaders second; their leadership occurs as a by-product of their learning that opens many new possibilities for enhancing school performance. 


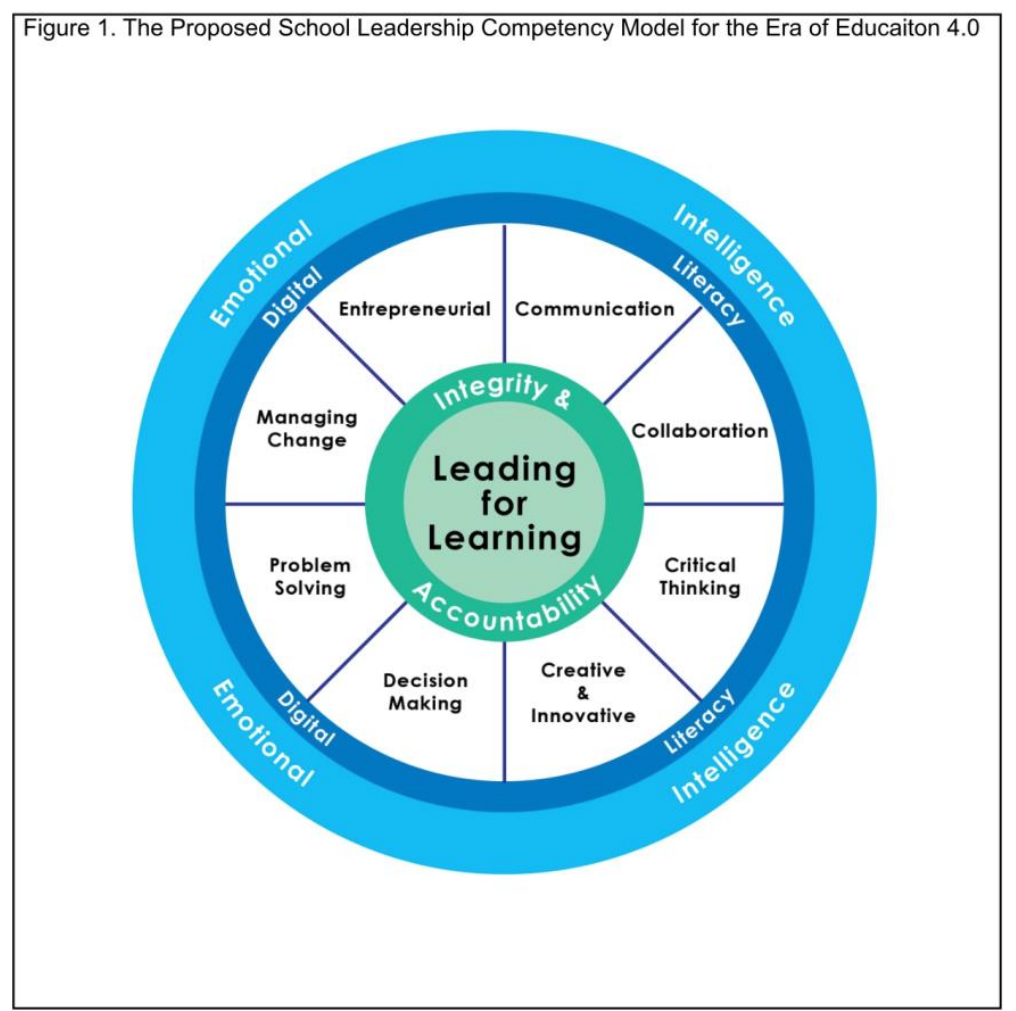

The outer ring of the inner circle is the competency of Integrity and Accountability. As schools are organizations contribute to the moral education of the young, school leaders have to prove that they are able to build moral communities by sustaining moral leadership in the day-to-day management. Organizations need a culture of ethics to truly make their quality initiatives work and in fact it is the most critical variable in sustaining the performance of the organization (Maguad \& Krone, 2009; Wong, 1998). Simply put, the moral imperative of professional leadership is at the core of leadership (Lee, 2015).

There are another eight important competencies in the outer ring of the model. Communication refers to the extent how school leaders are able to communicate effectively their vision and beliefs by direction, words and deeds to achieve the school goals (Smith \& Riley, 2012). Communication is a social matter in which negotiating differences in understanding among communicators is a primary priority. Importantly, communication is crucial to decision making because the decision making process is increasingly interactive (Smoliar \& Sprague, 2003).

Collaboration focuses on leadership practice that the relations among school leaders, staff and stakeholders relate more to interactions than actions. Successful schools assume that school improvement and effectiveness is a collective rather than an individual enterprise (Tai \& Omar, 2018a). School leaders need to acquire the understanding, skills, and experience to collaborate successfully. Within the context of Education 4.0, school leaders need to move away from being the sole decision maker to involving others in the decision making process that foster school effectiveness (Slater, 2005). 
Critical Thinking refers to the ability to analyze, evaluate, synthesize and using various types of reasoning as appropriate to the situation (Joe, 2011). More generally, it is about reasonable reflective thinking. Critical thinking is a necessary component of school change as school leaders who are strong critical thinkers see things from different perspectives and used to contextualize their worldview within a bigger picture. Particularly, critical thinkers consistently attempt to lead their organizations rationally, reasonably and empathetically (Mason, 2007).

Creative and Innovative is defined as the competence to demonstrate originality and inventiveness in work. Creativity is the ability to think outside the box and conceive new ideas, methods, materials, products and actions whereas innovation involves the creation of new knowledge or new combinations of old insights to make tangible and useful contribution in enhancing school effectiveness (Mainemelis, Kark \& Epitropaki , 2015; Moos, 2015).

Decision Making is the competence of making a choice among alternative courses of action (Smith \& Riley, 2012) that creates the right conditions for school effectiveness. Due to the more complex operational milieu in which school leaders are now working, school leaders need to confront and resolve conflicting interests as they endeavour to balance a variety of values and expectations in their decision-making. A skilful school leader needs to optimize his or her most valued beliefs, responsibilities and obligations to make good decision that minimize adverse consequences.

Problem Solving is defined as the ability to develop new ideas and solution or turn problems into opportunities (Angeli \& Valanides, 2012). As school leaders are those who spends a lot of time solving instructional problems in the school, and whose performances in solving those problems have a tangible effect on the results of the students at the school, they need an expert's ability to use particular processes to help the school to be more effective and successful.

Managing Change refers to the competence to induce change, getting others to change, upholding and champion constant change in schools (Tai \& Omar, 2018a). The process of leading and managing school change in the current era is becoming more complex and this has placed school leaders centre stage as the persons responsible for the implementation of these changes and accountable for results. Yet, balancing the demands of public accountability on national tests with the educational needs of all students is a problematic balancing act for most school leaders (Holmes, Clement \& Albright, 2013).

Entrepreneurial is defined as the ability to organize and manage school enterprisingly with considerable initiative and risk to create opportunities for betterment of the school (Akbar \& Obaid, 2014). According to Woods (2015), entrepreneurialism has been strongly advocated in Western education policy as requisite to creatively and constructively managing the challenges and risks of the performative era. As it helps school leaders to be sensitive and responsive to issues of context, points to the progressive and transformative possibilities, it is imperative for them to equip with the concerned competence.

Besides, the proficiency in the usage of the technologies and the ability to promote a school culture that encourage the integration of ICT in teaching, learning and management or Digital Literacy is considered as a key competency to educational quality (Purvanova \& Bono, 2009). The era of Education 4.0 is all about embracing digital technology. Despite of obtaining high level of digital literacy, the main task of school leaders in this era is how to increase pedagogically meaningful use 
of ICT in class and out of class that promotes teaching and learning appropriate for the needs of 21stcentury students.

Emotional Intelligence (EI) is a set of abilities involved in reasoning about emotions, and using emotions to inform cognitive activities such as reasoning and problem solving (Omar \& Tai, 2018b). $\mathrm{El}$ is located at the outer ring of the whole model as it is the basic competency that school leaders need to apply across the complete terrain of the organization. School leaders must be able to run organizations that address the emotional well-being of staff and students if it is to be effective. These are the interpersonal and adaptive competencies that the school leaders conduct themselves and interact with the working environment that makes human work more efficient.

\section{The importance of the School Leadership Competency Model for the era of Education 4.0 (SLCMEdu4.0)}

The development of School Leadership Competency Model for the era of Education 4.0 (SLCMEduc4.0) is an important effort for identifying the most effective competencies of school leaders in enhancing school effectiveness by taking into consideration the challenges of the era of Education 4.0 from local educational perspective. Such initiative is parallel with the 5 th shift of the eleven operational shifts prioritized in the Malaysia Education Blueprint 2013-2025 ---'Ensure highperforming school leaders in every school'. It would contribute to school improvement and overall effectiveness of schools across nation whereby effective school leadership is rely on the performance of school leaders that basically links significantly with their professional competencies.

Specifically, from a human resource development perspective, the model is an effective training needs analysis tool that can provide useful feedback in designing future training programs for school leaders in enhancing their competencies in school effectiveness. These critical competencies can be learned, and a greater understanding of their influence can help the Ministry of Education to engage resources more effectively to equip school leaders with relevant competencies in meeting the needs and challenges of Education 4.0. The study will equip the State Department of Education and District Department of Education with information about the professional performance of school leaders based on competency in leading schools in the era of Education 4.0. Such understanding will provide practical insights on how to effectively manage school leaders' professional development programmes; professional development is a coherent part of school reform that promotes and maximizes the individual and shared learning of the school leaders.

The SLCMEduc4.0 can also be used as an important indigenous model in conducting educational leadership courses and postgraduate studies offered by the local universities. The SLCMEduc4.0 not only adds to the body of knowledge on educational leadership, it will expand and enhance the understanding of the students on school leadership professional development in a local context in adapting to the demands of Education 4.0. In terms of research, the SLCMEduc4.0 will offer a promising new instrument for measuring school leadership competency in the Malaysian context. With good validity and reliability, this instrument can provide local as well as international researchers with more evidence-based and timely assessment. 
INTERNATIONAL JOURNAL OF ACADEMIC RESEARCH IN BUSINESS AND SOCIAL SCIENCES Vol. 9, No. 4, April, 2019, E-ISSN: 2222-6990 @ 2019 HRMARS

\section{Conclusion}

Building a conceptual framework is the most basic step in conducting a meaningful study. The conceptual framework of the current study may help to understand and explain the critical leadership competencies that facilitate change in schools in the era of Education 4.0. The increasing demands for school reforms in the era of Education 4.0 continuously challenge the roles of school leaders. As schools continually embark on programmes pertaining to school effectiveness, school leaders need to equip themselves with subsequent competencies so as to transform the school system effectively. No school leader will embrace any school change if he/she is unable to perform the new task competently. On a practical level, this study proposes the SLCMEduc4.0 to promote successful educational leadership development that is appropriate for both the professional development activities of present school leaders, and particularly, set qualification criteria for prospective school leaders. In summary, the study may enhance the leadership development of Malaysian school principals towards productive change in the era of Education 4.0.

\section{References}

Abrahamsen, H., \& Aas, M. (2016). School leadership for the future: Heroic or distributed?

Translating international discourses in Norwegian policy documents, Journal of Educational Administration and History, 48(1), 68-88.

Akbar, F., \& Haitham Obaid, A. A. (2014). Explaining the relationship between creativity, Innovation and entrepreneurship. International Journal of Economy, Management and Social Sciences, 3(12), 1-4.

Angeli, C., \& Valanides, N. (2012). Epistemological beliefs and ill-structured problem-solving In solo and paired contents. Educational Technology and Society, 15(1), 2-14

Bharwani, S., \& Talib, P. (2017). Competencies of hotel general managers: A conceptual Framework. International Journal of Contemporary Hospitality Management, 29, 393-418. doi: 10.1108/IJCHM-09-2015-0448

Bitterova, M., Haskova, A., \& Pisonova, M. (2014). School leader's competencies in Management area. Procedia Social and Behavioural Sciences, 149, 114-118.

Brown-Martin G. (2018). Education and the Fourth Industrial Revolution. Retrieved from https://medium.com/learning-re-imagined/education-and-the-fourth-industrial-revolutioncd6bcd7256a3

Bueno, C., \& Tubbs, S. (2005). Identifying global leadership competencies: An exploratory Study. The Journal of American Academy of Business, 5(1/2), 80-87.

Day, C., \& Sammons, P. (2013). Successful leadership: A review of the international literature. CfBT Education Trust, UK: The University of Nottingham.

Dubovicki, S, \& Jukic, R. (2017). The importance of acquiring pedagogical and didactic Competencies of future teachers - the Croatian context. Early Child Development and Care, 187(1), 1557-1567. doi: org/1080/03004430.2017.1307839 Drydale, L., \& Gurr, D. (2011). Theory and practice of successful school leadership in Australia. School Leadership and Management, 31(4), 355-368.

Duffy, F. (2009). Change leadership competencies (Part 2). Retrieved from http://cnx.org/content/m19578/1.4/ 
INTERNATIONAL JOURNAL OF ACADEMIC RESEARCH IN BUSINESS AND SOCIAL SCIENCES Vol. 9, No. 4, April, 2019, E-ISSN: 2222-6990 @ 2019 HRMARS

Freeman, R.E., \& Auster, E.R. (2011). Values, authenticity and responsible leadership. Journal
of
Business
Ethics,
98(1),
$15-23$.

Gray, S. P., \& Streshly, W. A. (2010). Leading good schools to greatness: Mastering what great principals do well. Alberta: Sage Publication.

Hallinger, P. (2011). Making education reform happen: Is there an 'Asian' way? Retrieved From http://www.ied.edu.hk//apclc/roundtable2011/paper/Philip\%20Hallinger.pdf.

Hallinger, P., \& Huber, S. (2012). School leadership that makes a difference: International Perspectives. School Effectiveness and School Improvement, 23(4), 359-367.

Hallinger, P., \& Walker, A. (2017). Leading learning in Asia: Emerging empirical insights from Five societies. Journal of Educational Administration, 55(2), 130-146. doi: 10.1108/JEA-02-20170015

Herold, G. (2016). Leadership in the Fourth Industrial Revolution. San Francisco: Stanton Chase. Retrieved from https://executiveacademy.at/fileadmin_synced_ assets/documents/White_Papers/Leadership-in-Fourth-Industrial-Revolution-StantonChase.pdf

Holmes, K., Clement, J., \& Albright, J. (2013). The complex task of leading educational Change in schools. School Leadership and Management, 33(3), 270-283. doi: 10.1080/13632434.2013.800477

Huber, S.G., \& Muijs, D. (2010). School leadership effectiveness: The growing insight in the Importance of school leadership for the quality and development of schools and their pupils. In S.G. Huber (Ed.). School leadership: The International perspectives (pp. 79-100). Dordrecht, The Netherlands: Springer.

Joe, Y. F.L. (2011). An introduction to critical thinking and creativity: Think more, think better. United State: John Wile \& Sons.

Lappalainen, P. (2015). Predictors of effective leadership in industry: Should engineering Education focus on traditional intelligence, personality, or emotional intelligence? European Journal of Engineering Education, 40(2), 222-233.

Lee, W. O. (2015). Moral leadership: Where the East meets the West. Multicultural education Review, 4(1), 29-50. doi: 10.1080/23770031.2009.11102888

Leithwood, K., Harris, A., \& Hopkins, D. (2008). Seven strong claims about successful school Leadership. School Leadership and Management, 28, 27-42.

Maguad, B. A., \& Krone, R. M. (2009). Ethics and moral leadership: Quality linkages. Total Quality Management, 20(2), 209-222.

Mainemelis , C., Kark , R., \& Epitropaki , O. (2015). Creative Leadership: A Multi-Context Conceptualization. The Academy of Management Annals, 9(1), 393-482.

Mason, M. (2007). Critical thinking and learning. Educational Philosophy and Theory Banner, 39(4), 339-349. doi: 10.1111/j.1469-5812.2007.00343.x

Ministry of Education Malaysia (2016). Malaysia education blueprint 2013-2025: 2016 annual Report. Putrajaya: Ministry of Education Malaysia.

Mohamed, Valcke, M., \& De Wever, B. (2017). Are they ready to teach? Student teachers' Readiness for the job with reference to teacher competence frameworks. Journal of Education for Teaching, 43(2), 151-10. doi:org/1.1080/02607476.201.1257509 
INTERNATIONAL JOURNAL OF ACADEMIC RESEARCH IN BUSINESS AND SOCIAL SCIENCES Vol. 9, No. 4, April, 2019, E-ISSN: 2222-6990 @ 2019 HRMARS

Moos, L. (2015). Leadership for creativity. International Journal of Leadership in Education, 18(2), 178-196. doi. 10.1080/13603124.2014.915060

$\mathrm{Ng}$, F. S. D. (2015). Leadership learning for complex organizations. Cogen Education. Retrieved from http://dx.doi.org/10.1080/2331186X.2015.1017312

O'Flaherty, J, \& Beal, E. M. (2018). Core competencies and high leverage practices of the Beginning teacher: A synthesis of the literature. Journal of Education for teaching, 44(4), 461478.doi: org/10.1080/02607476.218.1450826

Petrie, N. (2014). Future trends in leadership development. Colorado Springs: Centre For Creative Leadership.

Purvanova, R. K., \& Bono, J.E. (2009). Transformational leadership in context: Face-to-face And virtual teams. Leadership Quarterly, 20, 343-357.

Samuel, M., Tee, M. Y., \& Pe Symaco, L. (2017). Education in Malaysia: Development and Challenges. Singapore: Springer Nature Singapore Pet Ltd.

Shet, S. V., Patil, S. V., \& Chandawarkar, R. M. (2017). Framework for methodical review of Literature on leadership competencies, Cogent Business and Management, 4. Retrieved from http://dx.doi.org/10.1080/23311975.2017.1309123

Slater, L. (2005). Leadership for collaboration: An affective process. International Journal of Leadership in Education, 8(4), 321-333. doi: 10.1080/13603120500088745

Smith, L., \& Riley, D. (2012). School leadership in times of crisis. School Leadership and Management, 32(1), 57-71.

Smoliar, S. W., \& Sprague, R. (2003). Technology Support for Communication and Understanding, Journal of Decision Systems, 2(2), 123-139. doi: 10.3166/jds.12.123-139

Tai, M. K., \& Omar, A. K. (2018a). A comparative analysis on principal change Leadership competencies in Malaysian high- and mediocre-performing secondary schools. Asia Pacific Journal of Education. Advance online publication. doi:10.1080/02188791.2018.1476319

Tai, M. K., \& Omar, A. K. (2018b). Emotional intelligence of school Principals in managing Change: A comparison among high, mediocre and low-performing secondary schools in Malaysia. International Studies in Educational Administration, 46(3), 67-88.

Tai, M. K., \& Omar, A. K. (2018c). The relationship between emotional intelligence of school principal in managing change and teacher attitudes towards change. International Journal of Leadership in Education ----

Theory and Practice. doi:org/10.1080/13603124.2018.1481535

Tang, S. Y. F., Wong, A. K., \& Cheng, M.M.H. (2015). The preparation of highly motivated and profesionally competent teachers in initial teacher educatio. Journal of Education for Teaching, 41(2), 12-144. doi:org/10/108002607476.2015.1010875

Townsend, T. (2011). School leadership in the twenty-first century: Different approaches to Common problems? School Leadership and Management, 31(2), 93-103.

Welch, J., \& Hodge, M. (2018). Assessing impact: The role of leadership competency models In developing effective school leaders. School Leadership and Management, 38(4), 355-377. doi: 10.1080/13632434.2017.1411900

Wendy Pan, H., Nyeu, F., \& Cheng, S. (2017). Leading school for learning: Principal practices In Taiwan. Journal of Educational Administration, 55(2), 168-185. doi: 10.1108/JEA-06-2016-0069 
INTERNATIONAL JOURNAL OF ACADEMIC RESEARCH IN BUSINESS AND SOCIAL SCIENCES

Vol. 9, No. 4, April, 2019, E-ISSN: 2222-6990 @ 2019 HRMARS

Wong, K. (1998). Culture and moral leadership in education. Peabody Journal of Education, 3(2), 106-125. doi: 10.1207/s15327930pje7302_5

Woods, P. (2015). Sense of purpose: Reconfiguring entrepreneurialism in public education. Advances in Educational Administration, 19, 223-241. 